\title{
The reflexive imperative among high-achieving adolescents
}

\section{A Flemish case study}

\author{
Inge Van Lancker \\ Ghent University, Belgium
}

The socio-cultural conditions of late modernity induce a "reflexive imperative" amongst young people, which also results in metapragmatic and metalinguistic behaviour, as has been demonstrated by linguistic ethnographers (LE). However, recent LE studies on reflexivity in Western European settings have mainly focused on how groups of socially low-status, geographically mobile and multilingual youth are involved in creative linguistic processes in which the disapproval of their linguistic hybridity is denounced. In this paper, based on a linguistic-ethnographic study, I will uncover the influence of the reflexive imperative on a different group: six high-achieving, white, elite, male, adolescent pupils in Flemish Belgium. Through a micro-analysis of their metacommentaries and speech practices, I describe the subtle metalinguistic and metapragmatic moves of the pupils, which demonstrate their attitude towards standard language use at school. An analysis of these boys' linguistic reflexivity demonstrates a complex attitude towards Standard Dutch and Standard Language Ideology: at first sight, they seem to incline towards linguistic equality, resulting in a relaxation of the standard norm. However, an analysis of the more indirect metapragmatic practices of these boys reveals how they strategically use the symbolic capital of Standard Dutch, a practice which echoes the Flemish language-in-education policy and might serve to preserve (or prepare) their (future) elite position in society.

Keywords: linguistic ethnography, Flanders, Standard Language Ideology, linguistic reflexivity, language and education 


\section{Introduction}

According to the sociologist Margaret S. Archer, socio-cultural changes associated with late modernity have, "for the first time in human history, [made] the imperative to be reflexive [...] categorical for all" (Archer 2012: 1). Due to late modern trends such as informalisation, democratisation, globalisation, immigration and expressions of anti-authority (Giddens 1991), social subjects in western institutional spaces are ever more confronted with new situational contexts in which their "ability [...] to consider themselves in relation to their (social) contexts and vice versa" (Archer 2012:1) is triggered time and again. Given that the above mentioned tendencies associated with late modernity also destabilise "abstract notions of standard languages, uniform views of speakers and stable group identities" (PérezMilans 2015: 101), it is not unthinkable that the "reflexive imperative" (Archer 2012: 1) equally brings about reflexivity among language users trying to make sense of their own language use and that of others and of the (social) identities connected with it (also see Pérez-Milans 2017). However, scholars (e.g. Bourdieu 2001) focusing on reflexivity in their research, tend to propagate a critical stance towards (their own) scientific work or towards the construction of scientific knowledge in general, instead of looking into the reflexive praxis of language users. In this paper, I want to look at this reflexive praxis in more detail, but first, I will explain what I understand by the reflexive praxis of language users.

Following Silverstein (1993:36) we assume that language is indexical, and each "signal form as occurring either PRESUPposes (hence, indexes) [...] or ENTAILS ["CREATES"] (and hence indexes) something about its context-of-occurrence" (emphasis in original). In other words, a linguistic unit can either refer to its indexical appropriateness or to its indexical effectiveness in its context. These two semiotic functions need not display any correspondence or coherence. However, discursive interaction does "seem to have a coherence as a dynamic event" (Silverstein 1993:36). This means that there needs to be a mediating functional modality, which is called "the metapragmatic function of occurring sign-forms" (ibid.). Thanks to this function, language users dispose of models for the kind of interaction they are in; they are aware of the unspoken rules that govern the interaction between them. This is what Silverstein calls metapragmatics (ibid.) and it is what I will be looking at in this paper. I will both be looking at how pupils infer the metapragmatic context explicitly, i.e. what I will call metalinguistic discourse, and at how they do this more implicitly, i.e. what I will call metapragmatic praxis. Insights in language users' metapragmatic practices and metalinguistic discourses might be very helpful to feed discussions about, for example, (the future of) standard languages in a globalised world where inter- and intralinguistic variation blooms. 
These insights might be especially relevant in a context like Flanders, the northern, Dutch-speaking part of Belgium. Here, the weakening position of spoken Standard Dutch (Grondelaers \& van Hout 2011:221) has created an emotion-charged discussion amongst Flemish linguists and policy makers about whether or not Flanders is turning into a destandardised region, or at least a region where standardisation has come to an end. Together with the loss of Standard Dutch, Flemish society is still considered to be a strong "standard language culture" (Milroy 2001: 539). In the first decade of the 21st century, this even led to a reinforcement of the standard in Flemish education as a cure against "the 'problems' of language deficiency and multilingualism” (Delarue \& De Caluwe 2015:200-201) associated with the (ethno-)linguistic diversity brought about by the late modern trends mentioned above. The Flemish language-in-education policy documents produced in that period (Smet 2011; Vandenbroucke 2007) are pervaded by what is called a Standard Language Ideology or SLI (Milroy \& Milroy 1985). This ideology, based on not only a hierarchy of languages (with the standard at the top), but also of language users and interactional situations (with standard language users and formal situations at the top), in fact aims for linguistic and social equality.

The idea is that, if everybody uses the standard, social discrimination on the basis of linguistic competence is no longer possible. However, in practice, this ideology reinforces social inequality by excluding from elite positions in society language users who do not (or are not able to) use the standard. This side effect of the SLI contrasts sharply with the proclaimed egalitarian, democratic and horizontal tendencies described by sociologists as characteristic of late modern social life. In this paper, I make the assumption that this tension between a daily school life where (linguistic) equality and "linguistic norm relaxation" (Grondelaers \& van Hout 2011:224) seems to be the rule and a language-in-education policy which, strictly spoken, proclaims that the standard norm is the only linguistic variety to be used, stimulates the linguistic reflexivity of pupils and teachers.

In what follows, I will report on the linguistic reflexive praxis of a specific group of pupils (cf. infra) in a linguistic-ethnographic study. The study departs from the conviction that "the social judgments of language use that matter most may even remain below the level of metalinguistic formulation" (Coupland \& Kristiansen 2011:22) and therefore combines interview data - to grasp the pupils' metalinguistic discourse - and interactional data - to illustrate their more subtle metapragmatic moves, linguistic games and stylisations in concrete, daily interactions. National and international examples have demonstrated that this combination can be very fruitful. Rampton (2003), for example, investigated the language use of adolescents in an inner city school in London and he determined that pupils" stylisations were "spontaneous moments when [...] youngsters were artfully reflexive about the dichotomous values that they tacitly obeyed in the variability of their routine speech" (2003: 75). In other words, in their routine 
speech, these youngsters implicitly endorsed the linguistic values present in their environment, but when stylizing language, these values were challenged or even criticized in a playful or artful way. Jaspers (2005) made similar observations in his research on adolescents of Moroccan descent in a Flemish secondary school.

The novelty of this research does not lie in the fact that it is the first ethnographic investigation into the reflexive practices of pupils of this age group (see for example the above mentioned studies by Rampton and Jaspers). However, most of the research attention in linguistic ethnography has gone to groups of immigrant adolescents in urban contexts (but see Bucholtz 1999, 2011) who often do not possess the linguistic capital (cf. Bourdieu 1991) valued in society and whose own linguistic knowledge or capacities are sometimes even considered inadequate in school contexts (as Martín Rojo 2010 illustrates). Linguistic ethnographers tend to look at how processes associated with late modernity stimulate these youngsters' linguistic reflexivity, which results in creative practices such as "crossing" (Rampton 2005), "linguistic sabotage" (Jaspers 2005) and "polylingual languaging” (Jørgensen 2008) which might sometimes even have a strong political loading. The pupils of my research project are in a fairly different situation. They are all native speakers of Dutch (except for 3), ${ }^{1}$ live in a more rural area of the country, belong to the higher middle class and follow general secondary education (which means that they are preparing for higher education).

In addition, this paper particularly focuses on a group of six high-achieving boys: Arnoud, Jerom, Koen, Thomas, Tijl and Vincent. Considering their current field of study (sciences) and their aspirations for the future, ${ }^{2}$ these boys might belong to the future economic and cultural elite of Flanders. As a result, they have social and linguistic symbolic capital at their disposal. We might wonder then whether these boys' reflexive praxis displays a similar critical stance towards the propagated linguistic system as that of the above mentioned adolescents. After all, these boys occupy a relatively privileged position in their environment, both linguistically (they can speak (Standard) Dutch) and socially (they belong to the higher middle class and have a rather successful school career). Chances are therefore that the democratic, informalising and globalising forces of late modernity might have a different effect on the linguistic reflexive praxis of these youngsters than on that of the youngsters in the above mentioned studies.

1. Fiona, Kasper and Rani are non-native speakers of Dutch, but they do reach a fairly high level of language proficiency in Dutch. Besides, they are not central to the analyses presented in this paper. Therefore, I will not expand on their linguistic background here.

2. The boys' aspirations for the future range from studying at the university (Movement Sciences, Engineering, Chemistry, Physiotherapy) until becoming a pharmacist or having a job in the army or the police. 
In the following paragraphs, I will first expand on the research context, the data collected in that context and the methods of analysis. After that, I offer the analysis of selected extracts from the data which show that these pupils' metalinguistic discourse demonstrates their preference for linguistic horizontality, while at the same time they sometimes endorse the SLI propagated by the school for strategical reasons. Later, I discuss whether this vision can be transferred to the pupils' lives outside of the school as well. Finally, in the concluding remarks, I try to put my analysis into a wider perspective and I touch upon opportunities for further research and for policy making.

\section{Research context, data collection and data analysis}

This paper is based on a sociolinguistic-ethnographic study at Westbank High, ${ }^{3}$ a public secondary school in Oudenaarde, a small town of approximately 30000 inhabitants in East-Flanders, Belgium. The aim of the research project is to describe and explain the linguistic behaviour, perceptions and attitudes of 37 pupils of 16-18 years old. In the linguistic-ethnographic tradition of trying to get a "worm's eye"-perspective (Rampton 2001) or to dig very deeply into the selected context, I collected different types of data from November 2013 until May 2015. During the first year of the research (November 2013-May 2014), I was present in the school buildings approximately five hours a week, in order to observe the pupils in different school situations, to record their language use in those situations or to conduct sociolinguistic interviews. In the second year (September 2014 - May 2015), for approximately 2.5 hours a week, I checked the preliminary analysis of my data with the pupils by means of observations, informal chats and feedback interviews (cf. Jaspers 2005). In the course of these two years, I not only collected 16 hours of audio-recorded interviews and 35 hours of audio recordings of pupils' speech in various school situations, but also over 250 pages of field notes which contain a wealth of "ethnographic knowledge" (Blommaert 2007), i.e. profound etic and emic insights (Hymes 1964:26) into the context at hand, which serve to frame, contextualise, nuance or complement the analyses. These emic insights, as Heller (2008: 250) argues, help us to understand "how language practices are connected to the very real conditions of people's lives, to discover how and why language matters to people in their own terms". Given that this paper explores reflexive practices of concrete language users, this perspective might be very insightful.

A detailed interactional analysis (cf. Rampton 2010) of selected segments of these data - such as the analyses presented below - enables us to uncover the

3. The name of the school as well as pupils' and teachers' names used in this paper are pseudonyms. 
reflexive practices of this particular group of high-achieving pupils in different situations. Furthermore, like most linguistic-ethnographers, I try to zoom in and out (Nicolini 2009: 17) simultaneously, by investigating both the linguistic behaviour of language users (and their motives for that behaviour) in situ and at the same time, focusing on context. A criticism commonly passed on linguistic ethnographers is that they only have data on a very specific situation, but, as Rampton et al. (2004:15) argue, "they encounter huge quantities of language, and if they narrow their units of analysis from situations to particular language practices [my emphasis, ivl], the scope for generalisation is substantially increased". For this paper, it means that if we focus on the micro level of particular reflexive practices (for example the stylisation of Standard Dutch) instead of on reflexive situations (for example the evaluation of a pupil's language use by another pupil) we might uncover reflexive practices which could also be encountered in different situations and with different language users. These possibilities for further research are touched upon very briefly in the last section.

\section{Reflexive practices of six late modern adolescent boys in a Flemish school}

The late modern processes of democratisation, expressions of anti-authority and informalisation have reached the educational system in the western world, including Flanders (D'hoker \& Henkens 2005; Deumert \& Vandenbussche 2003). These processes not only affect the scale of schooling in general and make teacher-pupil interactions more horizontal, but they also affect the day-to-day language use in Flemish schools, resulting in more substandard language being heard in classrooms (Delarue 2013; Van Lancker 2016) . It is not surprising, then, that also the pupils in this study use a lot of non-standard features in their default school language. The pupils' deviations from standard Dutch consist mainly of

a. morphological features

- diminutives; e.g. spelleke for spelletje ('little game')

- personal pronouns; e.g. ge for je ('you - subj.')

- adnominal flexion; e.g. ne cola for een cola ('a coke')

b. reductionist practices

- deletions; e.g. omda for omdat ('because'), ma for maar ('but'), da for dan ('then')

- aphaeresis; e.g. oe for hoe ('how'), uis for huis ('house'), eeft for heeft ('has')

- syncopes; e.g. a's for als ('if'), he'maal for helemaal ('completely')

$-\quad \ldots$ 
These deviations are more or less prominent depending on the specific situation in which the pupils find themselves. So although the pupils use more non-standard features in the playground than when answering a question in the classroom or when giving an oral presentation, their routine speech style in most of the observed situations can still be labeled substandard language use. The rare occurrence of Standard Dutch appears to be a confirmation of the hypothesis of destandardisation in spite of the government's efforts to establish the standard as the only possible school language.

In this paper, I argue that this particular tension, between a horizontal teacher-pupil relationship and a democratic atmosphere characterised by the use of substandard language, on the one hand, and the (re-)enforcement of standard language use through the policy, on the other, stimulates linguistic reflexivity among the group of pupils under investigation. In the following paragraphs, two of the reflexive practices demonstrated by the pupils are analysed. The following section discusses the pupils' comments on pupil-teacher (and teacher-pupil) interactions and on language use in school situations. After that, I analyse the meaning of metapragmatic moves in interactions in which pupils' stances towards Standard Dutch and the SLI become clear in a more indirect way.

\section{Metalinguistic discourse on pupil-teacher relations} and on language use at school

In the sociolinguistic interviews with the pupils, the influence of the processes of informalisation and democratisation on the school atmosphere becomes immediately clear. Almost all the interviewed pupils stated that they felt at ease in Westbank High, because of the relaxed atmosphere and because the school staff are far less strict on the pupils than in Saint Mary's College, a Catholic school for secondary education in the same city. The absence (or the rare occurrence) of teachers punishing pupils, the playful and teasing interactions between pupils and teachers - in which teachers know and ask about pupils' private lives (and vice versa), and the numerous teacher-pupil negotiations about teaching materials and evaluation witnessed at Westbank High during the period of data-collection indicate a fairly horizontal relationship between the teachers and pupils.

This horizontal relationship has consequences for the organisation of classroom interactions. Thirty years ago, Mehan (1985: 126) described the interactional behaviour of teachers in classrooms as follows:

[T] eachers not only allocate the floor, they take it back at the end of a student's reply or extended sequence of discourse. We seldom see students directly selecting the next speaker as part of their turn at talk during lessons. 
As Mehan describes it, the interactional rights of teachers and pupils in classroom settings were fairly unequal: teachers were allowed to allocate speaking turns and identify themselves as next speaker, while this power was not available for the pupils. In Westbank High, however, and supposedly in many more contemporary schools for secondary education in Western Europe (e.g. Rampton 2006), this teacher-favouring interactional structure is no longer dominant. Extract 1, for example, demonstrates how pupils can select themselves (as it occurs in everyday speech, cf. Mehan 1985) and others as the next speaker.

Extract 1. 20 January 2014 - Dutch Arnoud [1137-1159] ${ }^{4}$

1 Lerares: je krijgt binnenkort ook een euh een informatie een informatieve bundel van meneer Van Coppenolle ofwel gaat die op Smartschool aan jullie bezorgd worden (0.5) euh waar alles instaat wat je moet doen de stappen die je moet ondernemen (0.5) en euh dan gaan alle misverstanden wel euh verdwijnen

2 Koen: Vincent zijn't leuke opdrachten?

3 Lerares: goed

4 Vincent: 'k heb nog niet gekeken

5 Lerares: ja 't zijn leuke opdrachten ze zijn zo leuk -

6 Koen: maar voor u zijn die leuk ja maar voor ons niet

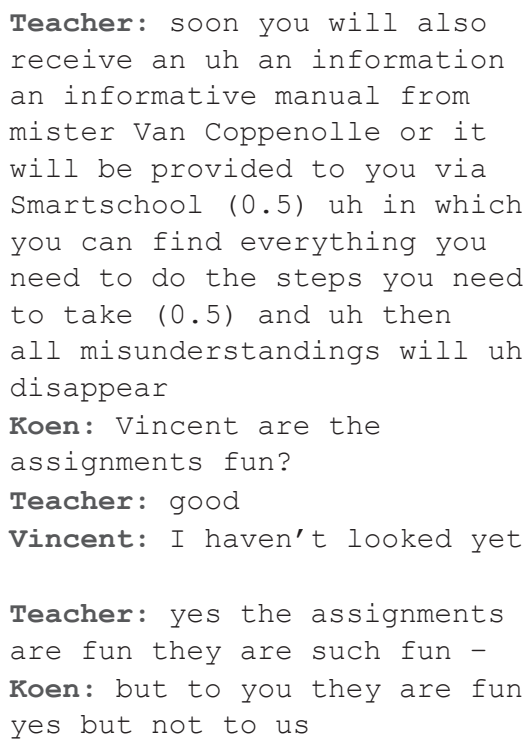

In Extract 1, the teacher is telling the pupils that they will receive a manual from mister Van Coppenolle with more information about the research project they need to work on during semester two. The pupils can choose between different assignments and since Vincent has claimed earlier (not in the transcript) that he wants to work on a project concerning Dutch language, Koen asks him about the assignments for Dutch in line 2. Doing so, Koen selects himself as the current and Vincent as the next speaker. The latter takes up that role in line 4. Nevertheless, one could claim that there is still a difference between the display of interactional power by Koen in Extract 1 and that of teachers in the description of classroom discourse by Mehan above. As it is, Koen asking Vincent a question in the classroom

4. This code indicates that it concerns a recording on the 20th of January 2014, that Arnoud was wearing the individual microphone during Dutch class and that the excerpt is taken from second 1137 until second 1159 in the recording. 
could be understood as “subordinate communication" in Goffman's (1981: 133) terms, and more specifically as "side-play". However, side-play can be defined as respectfully hushed words between bystanders, while Koen is clearly not muffling his utterance in Extract 1. It is pronounced loudly and clearly and since the teacher is responding to Koen's question in line 5, she classifies it as a legitimate classroom contribution. In the whole corpus, this practice of interactional self-selection by pupils during lessons occurred very often, especially among the six boys in focus in this paper. Episodes like the one illustrated in Extract 1 are possibly linked to a shift away from an interactional classroom structure where the teacher is in charge to a classroom setting where the interactional power is divided more equally between teachers and pupils (cf. Rampton 2006).

The relaxed atmosphere at Westbank High and the equal interactional relationship between teachers and pupils also reflect on the language use of both teachers and pupils. For example, when asked during an interview which kind of language the teachers use to talk to the pupils, Jerom answers "the same as we use". So teachers address pupils in their own language, i.e. the language that they normally use in school situations. Consequently, the pupils do not make an effort themselves to address the teachers in a more standard way. They justify that behaviour by stressing that the teachers approve of this procedure. According to Koen (see Extract 2), the default language use of the pupils - which is non-standard - is shared by the teachers, so that is why teachers do not mind not being addressed in Standard Dutch:

Extract 2. 11 March 2014 - INT 3 Jerom Koen Vincent [574-590]

1 Vincent: maar we spreken ook niet echt erg tegen under e (0.5) we $z^{\prime}$ we we letten er wel wat op e

2 Koen: maar gewoon normaal gelijk hoe dat zij praten

3 IVL: uhu

4 Vincent: ja

5 IVL: ja

6 Koen: dat is hetzelfde dus die horen dat (lachje) volgens mij niet dat is gewoon normal

7 IVL: uhu (1.0) uhu dus $z^{\prime}$ zoals dat gunder praat praten zij ook en daarom letten ze letten ze er niet op dat 't eigenlijk geen Algemeen Nederlands is ja

8 Vincent: ja is 't

9 Jerom: ja

10 Koen: ik denk dat ik ja zo denk ik
Vincent: but we don't speak so badly to them huh $(0.5)$ we $t^{\prime}$ we we pay some attention to it huh

Koen: but just normal like they talk

IVL : uhu

Vincent: yes

IVL: yes

Koen: that's the same so

they don't hear it (chuckle)

according to me it's just normal

IVL: uhu (1.0) uhu so $t^{\prime}$ the

way you talk is how they talk

and that's why they don't

notice don't notice that it is

not Standard Dutch actually yes

Vincent: yes it is

Jerom: yes

Koen: I think that I yes that's how I think 
In the interview with Jerom, Koen and Vincent, I (IVL in the transcript) ask the boys if teachers sometimes comment on the language they use to address them. They tell me that they don't and Vincent explains why (line 1): they "don't speak so badly" to teachers and they do pay some attention to their language use on that occasion. For these pupils, "paying attention to language" means "adapting it in the direction of the standard". Since the pupils rarely identify their language use as (an adaptation towards) Standard Dutch, Koen immediately states that they just talk to teachers as they normally talk, just as teachers themselves talk to them (line 2). In his next turn (line 6), he elaborates on that part of his statement, repeating that teachers' language use is the same as theirs and by amusedly (see his chuckle) saying that teachers therefore do not notice the way pupils address them. I rephrase that comment in line 7 and this rephrasing is confirmed by Vincent (line 8), Jerom (line 9) and Koen (line 10). So according to these boys, the default language use of the pupils equals that of the teachers - and it is implied that it diverges from the standard - and that is why teachers do not mind not being addressed in Standard Dutch.

By abstaining from using the standard when talking to teachers, the pupils seem to run counter to the SLI-influenced language-in-education policy in Flanders, inspired by the horizontal relationship between themselves and the teachers they perceive or aim at. However, at some occasions in the interviews, the pupils do portray the influence of that SLI-saturated policy. Extract 3, for example, shows that not all teacher-pupil relationships are the same. In this passage, the pupils talk about Ms. Vandenberghe, a teacher having greater authority than others, and consequently they address her with more deference, i.e. with more standard-like language.

Extract 3. 11 March 2014 - INT3 Jerom Koen Vincent [593-637]

1 IVL: ok en past ge u aan als

ge tegen ne leerkracht als

ge nu rechtstreeks aan een

leerkracht een vraag stelt

praat ge dan anders dan hier?

2 Koen: ik tegen sommige

leerkrachten

[...]

3 Koen: ik tegen leerkrachten waar dat ' $k$ een beetje (0.5) allé 'k ga als ik dat zo zeg banger van ben -

4 Vincent: ja

5 IVL: ja

6 Koen: - dan ga 'k misschien "u" zeggen
IVL: ok and do you assimilate when talking to a teacher when you are asking the teacher a direct question do you speak differently than here?

Koen: I do that with some teachers

[...]

Koen: I do it with teachers of whom I'm a bit (0.5) I mean I'm if I say it like that I am a bit more scared -

Vincent: yes

IVL: yes

Koen: - then I'll maybe use "you" 
7 IVL: echt waar gaat ge "u" zeggen? tegen wie zou ge zo "u" durven zeggen?

8 Koen: misschien mevrouw Vandenberghe misschien [...]

9 IVL: van mevrouw Vandenberghe hebben jullie schrik?

10 Koen: maar nee geen schrik maar

11 Vincent: maar schrik nu niet maar

12 IVL: maar die heeft wel gezag

13 Jerom: ja ja
IVL: is that true will you use "you"? with whom would you use "you" then?

Koen: maybe Ms. Vandenberghe maybe

[...]

IVL: you are scared of Ms. Vandenberghe?

Koen: but no not scared but

Vincent: but scared is not it but

IVL: but she has authority? Jerom: yes yes

Here, Koen nuances the argument made above that pupils just talk "normal" to teachers, by saying that it also depends on the teachers. Teachers perceived of as exercising authority over the pupils (as Ms. Vandenberghe) are addressed with more deference, for example with the formal standard personal pronoun $u$ ('you-singular-subject'), and not informal standard je or jij, or with the commonly used informal substandard ge or gij. Further in the interview, this hierarchical relation between Ms. Vandenberghe and the pupils becomes stressed even more when Vincent is recalling a situation in which Ms. Vandenberghe was angry with him and he had to apologize. Vincent explains that in that situation he did his very best to talk "really formally" and in the retelling of his words of that moment, he used mainly Standard Dutch, i.e. using formal $u$ instead of ge ('you') and pronouncing most words in their full form (instead of reducing them). Furthermore, he claimed that it was completely normal for him to speak that formally in that specific situation. Extract 3 thus demonstrates how the pupils are still influenced by the SLI, which propagates a hierarchy between linguistic varieties and contexts, with Standard Dutch and formal contexts (of which talking to Ms. Vandenberghe seems to be an example) at the top of those rankings.

In sum, during the sociolinguistic interviews, the six boys in focus in this paper emphasized the relaxed and horizontal relationship between them and the majority of their teachers. This egalitarian relationship (also witnessed by the author of this paper during ethnographic field work) and interactional equality (see the analysis of Extract 1) correlates with (or maybe even constructs) a linguistic convergence. The language use of teachers and pupils seems to be quite similar, which also means that the boys do not feel any motivation to talk in a more standard register when addressing a teacher (cf. Extract 2). However, when addressing a teacher who is considered to place herself in an authoritarian position (cf. Extract 3), this egalitarian vision on their linguistic behaviour is intruded by the SLI, which presupposes a hierarchic relation between interlocutors, contexts and different kinds of language use. 
Metapragmatic moves in interaction

In the previous section, I have argued that the contrast between a horizontal and democratic school atmosphere on the one hand and the SLI-influence of the language-in-education policy on the other causes a contradiction in the pupils' metapramatic comments. But while these metacommentaries might give the impression that the boys still prefer horizontality to hierarchy in their linguistic behaviour - given that they generally address their teachers in more or less the same way as they address each other - an analysis of the boys' metapragmatic moves in interactions has different outcomes. As it is, these subtle moves indicate that SLI does not only influence the linguistic behaviour of the pupils when they are talking to teachers who are said to impose a hierarchical distance between themselves and the pupils, but also when they talk to teachers with whom they normally have a very relaxed and informal bond. This influence can be witnessed in two extracts in which reflexive linguistic practices display the pupils' strategical use of the standard to get what they want from the teacher, or to evaluate the language use of a fellow pupil in a teasing way. These will be examined in turn below.

\section{Using Standard Dutch to get what you want from the teacher}

In Extract 4, the first seconds of a Dutch language class are presented. The pupils are just entering the room and they are finding themselves a seat. In the excerpt, deviations from Standard Dutch are underlined.

Extract 4. 17 March 14 - French Dutch Alison [3822-3847]

1 Lerares: ma mense wees nu ne keer verstandig (0.5) uit uzzelf (5.0)

2 Koen: wat is er mevrouw?

3 Lerares: dat ge verstandig moet zijn spontaan verstandig

4 Koen: spontaan verstandig

5 Lerares: ja en dus niet allemaal naast elkaar gaan zitte

6 Koen: a ja ok mevrouw

7 Tijl: ja ok Lothar gij gaat weg

8 Lothar: ma 'k zal 'k ik mij ier zettn

9 Vincent: ma ier kan da geen kwaad we zittn dicht bij jou

10 Koen: 'k zal de deur dicht doen

11 Lerares: (lacht)

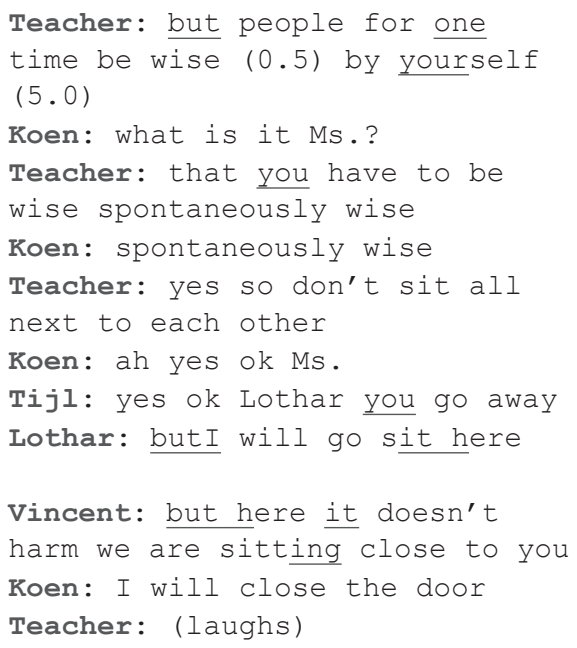

Teacher: but people for one time be wise $(0.5)$ by yourself (5.0)

Koen: what is it Ms.?

Teacher: that you have to be wise spontaneously wise

Koen: spontaneously wise

Teacher: yes so don't sit all next to each other

Koen: ah yes ok Ms.

Tijl: yes ok Lothar you go away

Lothar: butI will go sit here

Vincent: but here it doesn't harm we are sitting close to you Koen: I will close the door Teacher: (laughs) 
In general, the six boys have a very good relationship with Ms. Van Coster, the teacher of Dutch. They tell me in the interviews that they love the relaxed atmosphere in her lessons and that she explains the materials well (using many examples). On the other hand, they are also very loud and lively in her lessons. In fact, in these lessons, Arnoud, Jerom, Koen Thomas, Tijl and Vincent can be interpreted as "hyper-involved" boys (cf. Rampton 2006: 62): they ask the teacher questions before she has had the chance to explain something, they playfully criticise her, they doubt the content of her words, and they all do that - as they tell me themselves - by "shouting something for the whole class" instead of asking permission to speak or waiting their turn. This is what Alison ${ }^{5}$ in a feedback interview calls "playing with Ms. Van Coster" and she also wonders "how Ms. Van Coster is able to stand" that behaviour.

Considering this knowledge, we can interpret the first five lines of Extract 4 as Ms. Van Coster's attempt to prevent the hyper-involved behaviour of the boys: she wants them to spontaneously go and sit far from each other, so they cannot encourage each other in that behaviour. In the following lines, I will argue that the boys' responses to this attempt can be interpreted as metapragmatic moves in which they successfully use the Standard Language Ideology to get what they want from the teacher.

In Extract 4, Ms. Van Coster gives the pupils the somewhat vague instruction to "be wise for one time" (line 1). Koen responds to her instruction by asking what it is that Ms. Van Coster wants to say. The teacher rephrases her original instruction and Koen repeats her last two words in line 4 in order to ask for more clarification. Ms. Van Coster then explains what she means by "being spontaneously wise": she wants the boys not to sit next to each other. ${ }^{6}$ Koen confirms that he has understood the message ("a ja ok" ('ah yes ok')), while Tijl and Lothar propose a solution (Lothar will take another seat) and Vincent justifies the boys' current position by saying that "it doesn't harm" because they "are sitting close to" Ms. Van Coster. Finally, in line 10, Koen also proposes an action (closing the door) and the teacher laughs (line 11). Eventually, the boys manage to convince

5. Alison is not one of the pupils in focus in this paper.

6. Obviously, since she is not directing her instruction to any one in particular verbally, we cannot know whether the teacher addresses the boys here or not. However, I deduce that from several clues:

- in other observed Dutch lessons, the teacher applies the same strategy (relocating (some of) the six boys) in order to restore order in her classroom;

- only the boys (eventually) respond to the instruction of the teacher, which might suggest that they themselves interpret the instruction of the teacher as being addressed to them. 
the teacher that they "will be quiet" and they are allowed to keep their seats (which is not in the excerpt).

In this episode, the boys use three different techniques to get what they want from the teacher, i.e. to be allowed to keep their seats. One such strategy is proposing and executing a feigned solution for the problem signalled by the teacher. This is what Tijl and Lothar do by suggesting that Lothar should take another seat (line 7 and 8). If we look at the way the boys are positioned in the classroom (Figure 1) and if we acknowledge that Lothar does not belong to the peer group of the six boys, nor does he behave as one of the hyper-involved boys, it becomes clear that moving Lothar from his first (Lothar 1) to his second position (Lothar 2) does not really solve the teacher's problem. On the contrary, this replacement makes the contact between Tijl and Thomas, two good friends and part of the group of hyper-involved boys, easier.

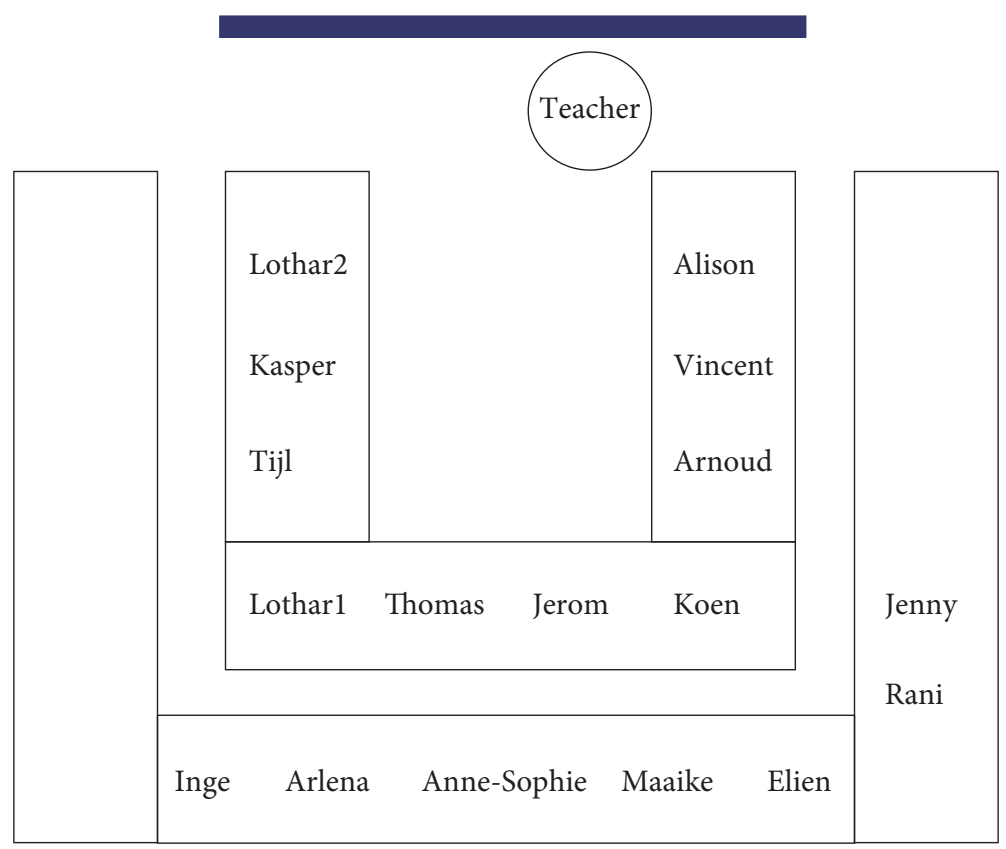

Figure 1. Position of the pupils in the classroom

The second technique is illustrated by Vincent (line 9), who tries to defend their current seating position by arguing that they will not be able to chat or to misbehave ("it doesn't harm") because they are sitting close enough to the teacher, so she can keep a close eye on them. 
The third strategy, which is the strategy most relevant for this paper, is demonstrated quite successfully by Koen (in line 2, 4, 6 and 10) and, to a lesser extent, by Vincent (in line 9). Both boys present themselves as good pupils willing to co-operate and to obey. Koen does that in two ways: by meeting the (conversational and other) expectations of the teachers and by using a very polite and standard language use. Vincent only uses this second procedure in a minimal way. We look at the first method (used by Koen only) first.

After the teacher has given her vague instruction in line 1, there is a pause of five seconds in which the pupils are finding their seats and are probably just ignoring the fact that the teacher has spoken. Nevertheless, Koen ${ }^{7}$ picks up the instruction of Ms. Van Coster and he asks for clarification (line 2). By doing that, he is meeting the conversational expectations of the teacher, which is also the case in line 4, when Koen repeats the last two words of the teachers' utterance in order to get even more clarification, and in line 6 , when he acknowledges the teacher's wish. In line 10, finally, he anticipates an instruction not yet given by the teacher, i.e. to close the door. By anticipating that instruction, once again Koen presents himself as a co-operative and reliable pupil. The teacher's laugh in line $11 \mathrm{might}$ indicate that she found Koen's behaviour rather unusual.

As mentioned above, this image of the good and helpful pupil is not only raised by the content of what Koen says, but also by the form. The teacher clearly does not initiate a conversation in Standard Dutch in line 1: she reduces standard maar ('but') to $m a$, uses the inflected form ne ('one/a'), instead of een, and addresses the pupils with the substandard form of the reflexive pronoun uzelf ('yourself-plural'), instead of using standard jezelf. As has been mentioned, it is not unusual for teachers using non-standard features when talking to pupils and vice versa. However, after a pause of approximately five seconds, Koen responds to her instruction in complete Standard Dutch and with the use of the honorific mevrouw ('Ms.'). Ms. Van Coster then rephrases her original instruction using more Standard Dutch, but still selecting the non-standard personal pronoun gij ('you-singular-subject') instead of standard jij. In the Flemish linguistic literature, the opposition of the so-called j-paradigm (including je/jij and jullie for singular and plural subject 'you' respectively, and jou and jullie for singular and plural object 'you' respectively) and the g-paradigm (including ge/gij and gunder for singular and plural subject 'you'

7. It is not clear why it is specifically Koen who answers and why it takes him so long. A hypothesis might be that the teacher is staring at him after uttering line 1. But since we lack video data and since there is no information about this specific interaction in the field notes, this remains speculative. 
respectively, and $u$ and under for singular and plural object 'you' respectively) is described as a very salient pair of standard- and non-standardness respectively (cf. Lybaert 2014; Van De Mieroop, Zenner \& Marzo 2016). Therefore, we can assume that Ms. Van Coster does not intend to speak Standard Dutch here. Still, through the rest of the conversation, Koen consistently utters his responses in impeccable Standard Dutch and he uses the honorific "Ms." once again in line 6. Since Standard Dutch is not his default language, nor is it the language he normally uses with teachers with whom he has a horizontal relationship, we can consider his standard use as a metapragmatic move.

During a feedback interview in which Arnoud and Vincent listened to the exact same excerpt, Arnoud called this practice "soft-soaping mockingly". I will analyse it more neutrally as a "performance", which according to Bauman (1987:8) may be seen as

a specially marked way of speaking, one that sets up or represents a special interpretive frame within which the act of speaking is to be understood. In this sense of performance, the act of speaking is put on display, objectified, lifted out to a degree from its contextual surroundings.

If we consider Koen's responses to the teacher as performances, we need to select a "special interpretive frame" to analyse them. I argue that, in this context, the use of Standard Dutch is used to speak "in altera persona" (Coupland 2001:349), that is by "exploiting linguistic resources normally not considered familiar, the speaker [can] project a different, often inauthentic and hypothetical identity that detaches the speaker from the indexical meaning of his or her default speech style" (Jaspers 2005:30 (my translation, ivl)). In other words, if Koen needs to present himself as the model pupil he is not, he needs to use "linguistic resources normally not considered familiar". For Koen, Standard Dutch is thus connected with a specific pupil identity of obedience and decency. Moreover, by using the variety the Flemish language-in-education policy prescribes, and in contrast with the teacher who is (at least in the beginning) not using policy-approved language, Koen makes it difficult for the teacher to punish him for his inauthenticity or performance and all the teacher can do is laugh (line 11).

In fact, Vincent does exactly the same thing, but less consistently. In line 9, when he is arguing why sitting next to each other is not "harmful" here, he uses a lot of non-standard language: reduction of maar ('but') to ma, h-aphaeresis in hier ('here'), t-deletion in dat ('that') and omission of the schwa in zitten ('to sit'). However, at the end of his utterance, he uses standard jou ('you-singular-object'), which is a very salient linguistic shift towards Standard Dutch because of two 
reasons. First, if we compare the standard and non-standard forms of the second person personal pronoun used by the pupils to address the teacher in the same recording, we see that line 9 contains the only standard use, compared to twenty instances of substandard use. ${ }^{8}$ Thus, standard jou is excluded from the default repertoire of these pupils and therefore we cannot interpret Vincent's use of jou as merely a slip of the tongue. Second, in this specific context Vincent could also have used the polite form of address $u$. This form would have been ambiguous, because it can be understood as the object form of the informal and non-standard g-paradigm, or as a polite form of address. By selecting jou instead, Vincent thus avoids this possible confusion and he seems to signal unambiguously that he is using Standard Dutch. Therefore, the use of jou by Vincent should be understood as a metapragmatic move by which he tries to convey the inauthentic image of the good pupil, as Koen does in the same excerpt.

To sum up, the reflexive performances in Extract 4 show us how these high-achieving boys - who normally prefer a horizontal linguistic constellation between themselves and the teachers -, can sometimes rely on the hierarchy of a SLI to convey a certain image and consequently to manipulate the teacher in a certain direction. In the next section, I will illustrate that these boys can also use the standard and the values connected to it to condemn each other's language use in class.

\section{Using Standard Dutch to reprimand a fellow pupil}

Extract 5 was taken from a mathematics lesson with Ms. De Vos, another teacher with whom the pupils have a very good relationship. The lesson is about probability and by way of example, the teacher and the pupils are solving a probability question together. The teacher has read aloud the assignment, she has asked some additional questions to prompt pupils' thinking and now she is asking them to make a calculation. In this extract, as in the previous one, deviations from Standard Dutch are underlined.

8. These numbers include 16 cases of generic pronouns of the type "kunt ge ook zeggen..." ('could you also say...'). In these cases, the teacher is not addressed directly as is the case in line 9 of Extract 4, but when using these generic pronouns the pupils still always directly talk to the teacher (although the other pupils can overhear what is being said). 
Extract 5. 29 April 2014 - MATH Vincent; [1063-1079]

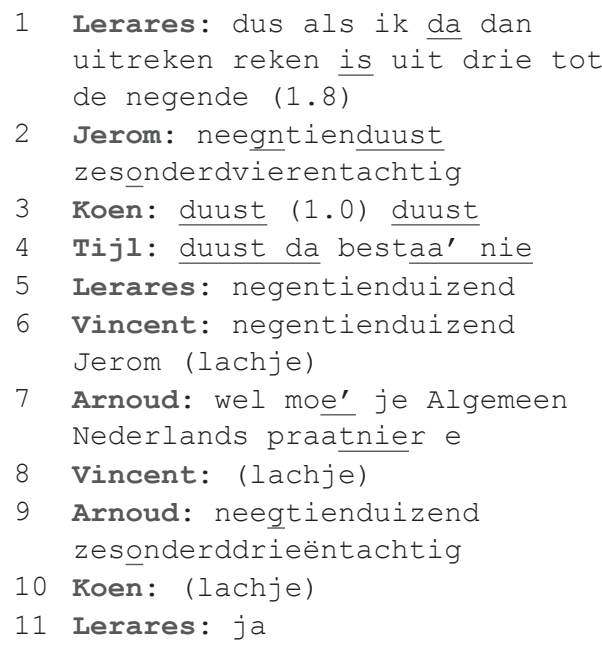

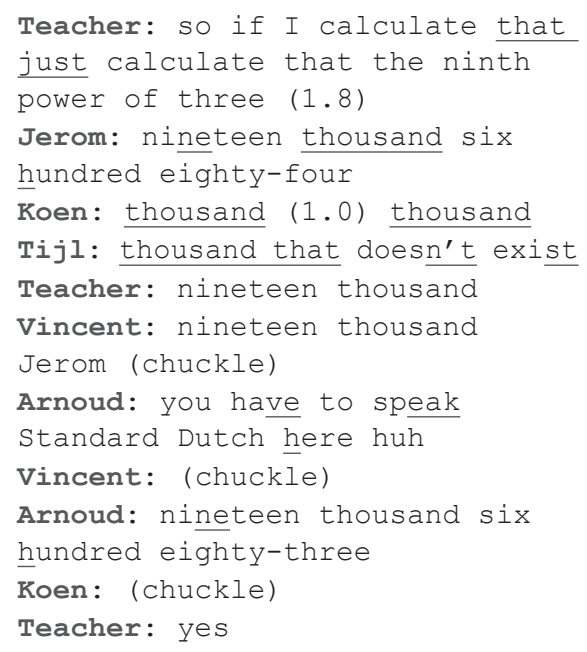

During the first five minutes of this lesson, Jerom was already very attentive and co-operative, giving answers before they were even asked. In Extract 5, we can see that it is again Jerom who gives the answer quite quickly (after 1.8 seconds). Presumably to avoid being considered a swot, Jerom violates the (implicit) school rules twice: he answers without asking permission to speak and he uses a fairly non-standard style, with the omission of the schwa in negen ('nine'), an h-aphaeresis in honderd ('hundred') and the use of the non-standard word duust ('thousand') instead of duizend. The first two infringements occur very often in the collected speech of the pupils and they are rarely commented on. Nevertheless, the latter feature - i.e. the use of duust instead of duizend - is less frequently used and becomes the object of different metapragmatic reactions: a disapproving repetition by Koen in line 3, a denial of the existence of the word duust by Tijl (line 4), a correction in Standard Dutch by Vincent (line 6) and one in intended Standard Dutch by Arnoud (line 9) and a mentioning of the linguistic norm in this context by Arnoud (line 7).

These reflexive practices, I will argue, are an outcome of the tension between a horizontal teacher-student relationship (which both corresponds with and depends on a linguistic norm relaxation) and a strong SLI-influenced language policy in schools: by using a linguistic resource which strongly diverges from the norm, i.e. duust, Jerom pushes the boundaries of what is linguistically possible in this situation and he consequently invites metapragmatic reactions which serve to re-establish the language norm (playfully, but still).

Which characteristics of duust contribute to the interpretation of the word as being "a strong deviation" from the norm and a way for Jerom "to push the 
boundaries of what is linguistically possible in this situation"? In other words, which aspects of duust make it suitable as object of reflexive practices? First, $d u$ ust is a clear lexical dialectal choice. According to Vandekerckhove and Nobels (2010), Standard Dutch and dialects overlap largely in their lexical component. Accordingly, a dialectal style is normally realized by means of phonological, morphological and morpho-syntactic features (Vandekerckhove 2005). Using a lexical dialect feature is therefore particularly noticeable or salient as a deviation from the standard. This is exactly what we see in Extract 5. In line 2, Jerom uses several non-standard features (cf. supra), but only the lexical deviation from the standard is focused on by the other pupils. Secondly, in the complete corpus of collected pupils' speech, duust only occurs six times, while its standard counterpart duizend occurs 29 times. This suggests that duizend is more central to the pupils' default linguistic style than duust. Furthermore, in five of the six cases where duust is used, it has the function of a vague quantifier (Norde, De Clerck \& Colleman 2014), like in the following example:

Liesbet: ${ }^{9}$ of wel doet ze anders duust kilo schmink aan

Liesbet: or maybe otherwise she wears a thousand kilos of make-up

Here, Liesbet does not mean that the girl she is talking about literally wears "a thousand kilos of make-up"; she just wants to make clear that she wears a lot. All the other attestations of duust in the corpus have this meaning of 'a lot', except for the one used in Extract 5, where duust refers to the number '1000'. Finally, Jerom's use of duust also invites linguistic reflexivity because he uses it in the classroom, when answering the question of the teacher. I have argued above that the pupils do not think it is necessary to adapt their language use when addressing a teacher with whom they have a horizontal relationship. However, the analysis of some interview fragments have also shown that this perspective of the pupils is not a strict rule (cf. supra). Apparently, using duust when answering the teacher's question is a bridge too far, because it unlocks a range of metacommentaries. In the first place, these comments serve to playfully put Jerom in his place, but besides that, they also re-establish the policy-propagated norm (Standard Dutch).

Considering the striking characteristics of duust, it is rather peculiar that the teacher - who could be considered as the voice of the language-in-education policy in practice - does not react to it. She only repeats the answer of Jerom in line 5 while she is writing it on the blackboard. Given the downward intonation of her sentence, her replacement of duust by duizend should not be interpreted as a reproach, but simply as a strategy to repeat the correct answer without using the non-standard word herself. Ignoring pupils' behaviour that deviates from the

9. Liesbet is not one of the pupils in focus in this paper. 
norm is an often observed tactic teachers use in their lessons. A teacher commenting on every pupil infringement hinders the progress of the lesson and is not able to reach his or her goal, in this case getting at the right outcome of the calculation.

Whether the teacher ignores Jerom's duust because she doesn't mind him using a dialect word or because she just wants to go on with the lesson, her attitude anyhow enables Jerom's peers to take up her role of corrector-evaluator. Here again (as in Extract 4) the boys therefore speak in "altera persona", or more specifically in "professora persona", i.e. taking on the interactional role of the teacher. They recall the official rule that pupils and teachers should use Standard Dutch in all school contexts (explicitly in line 7, but also indirectly by means of a correction in line 6 and 9), which makes it hard for Ms. De Vos to sanction these playful utterances. In fact, using school rules seems to be a "legal" way to brighten up the lessons (as has been observed by - among others - D’Amato 1993; Jaspers 2011, 2014), and therefore, the boys do not only use it in this lesson, but in several lessons where the relationship between them and the teacher is quite good.

One might wonder, however, what makes it probable that these boys' reflexive comments are triggered by the tension between a horizontal linguistic relationship between the teachers and the pupils and a Standard-Dutch-only policy. It might also be possible that these teasing comments of the boys are simply generated by the use of a word which is not so common in this situation (as illustrated above). Clearly, the whole interaction in Extract 5 is very playful and light (see, for example, the chuckles in line 6,8 and 10). However, it is clear that by using Standard Dutch to enact the evaluative teacher, the boys link standard language use and linguistic or interactional inequality between teachers and pupils (comparable results were found in, among others, Jaspers 2006; Madsen 2014). This clearly contrasts with their vision of teacher-pupil communication as horizontal and norm-free.

In sum, Extract 5 has demonstrated that pupils' use of salient non-standard features when talking to a teacher is one step too far in the process of norm relaxation or linguistic equality between teachers and pupils. As a consequence, this practice is being commented on, not by the teacher, but by fellow pupils, by means of a re-establishment of the SLI-influenced linguistic school rules. This re-establishment of the norm occurs in a playful and teasing way, and thus appears as just another of the pupils' strategies to liven up their school days. However, it also reveals the boys' awareness of the Standard Language Ideology and a deep understanding of the social personae associated with Standard Dutch (i.e. an exemplary pupil in Extract 4 or an evaluative teacher in Extract 5).

In the previous sections, I have tried to demonstrate that six boys' different metapragmatic moves originate in the tension between a democratic and egalitarian school environment and a language-in-education policy founded on linguistic and social hierarchy. The outcomes of these reflexive practices are quite complex, 
with an apparent inclination towards linguistic norm relaxation, on the one hand, and a strategical use of Standard Dutch and the social identities associated with it, on the other. One might wonder whether this very specific school-bound behaviour of the six boys has any relevance for their future linguistic behaviour or for their linguistic behaviour outside the school. That question is addressed in the following section.

\section{Transfer between school and the outer world}

It may be possible that the pupils in this study perceive their school environment as a very specific world in which, for example, their strategic references to the language policy make sense, while they are not used outside the school context. However, linguistically, the Flemish school environment resembles Flemish society in general to a large extent, since in the world beyond the school, the tension between horizontal social and linguistic relationships and a strong "standard language culture" (cf. supra) exists just as well. We might thus expect that the reflexive practices of the six boys have similar outcomes in non-school contexts as in school contexts.

Nevertheless, in this study, I only collected data in school situations, so I am not able to access the boys' indirect metapragmatic moves in the world beyond school, similar to those observed in Extract 4 and 5. What is possible, however, and what I have done too, is asking the pupils about their linguistic behaviour outside the school. In Extract 6, taken from the interview with Jerom, Koen and Vincent, we can witness Koen's struggle with his formulations when asked about his use of Standard Dutch outside school contexts.

Extract 6. 11 March 2014 - INT3 Jerom Koen Vincent [1094-1107]

1 IVL: ja en tegen wie zou ge dan nog buiten de school mooi AN spreken of spreekt ge enkel AN in de school? [...]

2 Koen: iedereen die belangr' allé die die hoger -

3 IVL: ja

4 Vincent: ja

5 IVL: iedereen die hoger is

6 Koen: - hogergeplaatst allé als dat nu nog kunt zeggen maar iemand die hogergeplaatst is ja
IVL: yes and with whom would you use proper Standard Dutch outside the school or do you only use standard Dutch in school? [...]

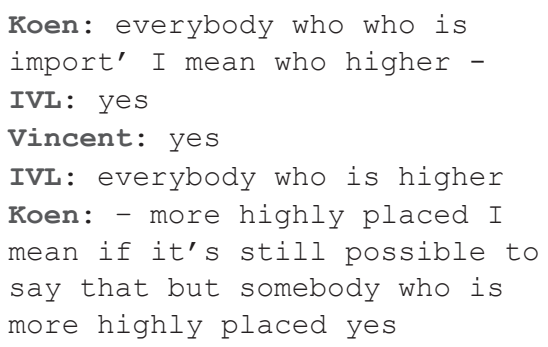


When asked with whom he would speak Standard Dutch outside of the school (line 1), Koen answers that he would use it with everybody who is (more) "important" or "higher" than he is (line 2). This idea is confirmed in the interviews with the other boys as well. Thomas, for example, explains that his father "is the boss" at work, and therefore he assumes that his fathers' employees address him in Standard Dutch, and Vincent asserts that he pays attention to his language use when "talking to someone important". However, although the idea that speaking to people more important or higher than you implies using Standard Dutch is shared among the boys, Koen does not seem to know exactly how to put that. We can see that he has difficulties expressing himself because he starts by saying belangrijk(er) ('(more) important') in line 2 but he replaces that word by hoger ('higher'). Still, his intonation (upward) and the grammatical incompleteness of his sentence (the verb is ('is') is lacking) reveal that he is not pleased with this word selection either and that he is going to extend his utterance. In line 6, Koen continues his sentence by now using the term hogergeplaatst ('more highly placed'). Again, he does not seem completely satisfied with his lexical choice, but he now uses a different strategy to show that: he explicitly asks himself whether it is still possible to say that somebody is more highly placed.

By doing that, Koen demonstrates that he understands the egalitarian and horizontal nature of, not only teacher-pupil relationships, but also of modern social life as a whole. On the other hand, by affirming that using the standard is the right way to talk to somebody "more highly placed", he endorses a SLI, which assumes a hierarchical relation between different kinds of language use and between different types of interlocutors (more high-ranking and more low-ranking ones). In other words, we can see that the linguistic choices to be made in the outer world are not as clear-cut for Koen as they are for Thomas and Vincent. This difficulty in Koen's answer originates - again - from the clash between a clear SLI which prescribes standard language use in formal situations (i.e. when talking to people more important than you are) and an abstract idea of Flemish society as an egalitarian world, where it is difficult to declare that some people are "more highly placed" than others. But although he has doubts about how to describe his point of view, Koen still endorses the SLI in non-school contexts, just as his peers Thomas and Vincent. Naturally, the analysis of Extract 6 needs to be supplemented with analyses of production data in further research. However, it gives us an idea of the way in which the boys deal with social and linguistic hierarchies in the world beyond school. 


\section{Conclusion}

In this paper I have argued that the field of tension originating from the opposition between a late modern horizontal (linguistic) relationship between pupils and teachers on the one hand and the enforcement of Standard Dutch as the only possible school language by policy makers on the other, fosters a linguistic "reflexive imperative" (Archer 2012) among six white, adolescent, high-achieving, Flemish, Dutch-speaking boys who belong to the (future) cultural and/or economic elite. An investigation of their metalinguistic discourse shows that, at first sight, these boys prefer linguistic equality, but that they do not wish to achieve this linguistic equality by proclaiming the general use of Standard Dutch (as would be the case if they were supporting the SLI-influenced policy).

On the contrary, they seem to opt for a relaxation of the norm and they do not really value the use of Standard Dutch in school contexts. A closer look, however, uncovers that this preference for linguistic horizontality between pupils and teachers should be nuanced: with some teachers and in some situations, the boys find it appropriate to use (more) Standard Dutch and in particular school situations, the traditional SLI-influenced linguistic hierarchy promoted by the language-in-education policy can be used strategically by the pupils to, for example, portray the image of the model pupil and, accordingly, to get your way, or to teasingly evaluate and correct the language use of a fellow pupil.

These findings indicate that, in fact, the democratic, informalising and globalising forces of late modernity have a similar effect on the linguistic reflexive praxis of these high-achieving, elite youngsters as on that of the youngsters described in earlier studies. Both the pupils represented in Rampton (1995), Jaspers (2005) and Jørgensen (2008), and the pupils described in this paper seem to perceive the linguistic inequality that surrounds them and they handle that inequality by using it in a creative way. However, there is an important difference in the linguistic reflexive praxis described here and that of the boys portrayed by Rampton, Jaspers and Jørgensen. Compared to the pupils described in the previous studies, the boys in focus here reach a high enough level of proficiency in the culturally prestigious linguistic variety (i.e. Standard Dutch) to be able to secure or affirm their dominant position at school and in society linguistically.

The Moroccan boys in Jaspers' study, for example, were proficient enough in Standard Dutch to stylise that variety when voicing social personae representing Belgian domination of the Moroccan boys or when expressing pretended enthusiasm about educational purposes or affected preparedness to co-operate in the linguistic study (Jaspers 2005:333). However, they were not able to use that kind of language in the same way as the boys described in this paper, nor strategically, nor routinely. The fact that Arnoud \& co are capable of using the standard in a very subtle and strategical way and the fact that they find it normal to use it routinely 
in more formal situations like giving oral presentations or apologising to Ms. Vandenberghe for improper behaviour may also suggest that the school context of West Bank High is not always as informal or norm-relaxed as it may seem. It is possible that the informality of the lessons should be understood as only a temporary relaxation of the pervading linguistic and social hierarchy. That hierarchy, of which the boys happily make use to base their own linguistic and social status on, is still present in educational rituals such as apologizing or formulating a request.

In the previous section, I briefly touched upon the boys' vision of language use outside the classroom. However, I argued that the data collected for this study are not suitable for making strong statements about how these boys perceive language in non-school situations and how they resolve to act in them. Further research could expand our scope by collecting interactional data in these contexts. Furthermore, an investigation of the perspective of Flemish teachers on the field of tension between horizontality and norm re-enforcement in school settings might be very interesting to look at. While Delarue (2013) already gives us a clear view on teachers' metadiscourse in interviews, there is still a need for interactional data which contain concrete metapragmatic moves teachers use to cope with this contrast, which they also consider problematic (cf. Delarue \& Van Lancker 2016).

The preliminary results of the research presented here do not only reveal opportunities for further research, but also for language education policy makers to improve that policy. That is to say, this paper demonstrates how adolescents have internalized the policy to a certain extent. However, the study has equally indicated how the internalisation of that policy still makes it possible for these pupils to use Standard Dutch strategically as a means of distinction. Pupils capable of playing with the linguistic resources considered normative are able to use that competence strategically to get what they want in school contexts, but also to put themselves higher than others as is the case in Extract 5, where playfully condemning the linguistic choice of a fellow-pupil also renders superiority to the condemners. By strategically deploying the denotations associated with Standard Dutch, these pupils manage to secure their dominant position, not only in the linguistic landscape of the classroom, but maybe even more broadly on the Flemish linguistic market or even the Flemish society as a whole. Pupils unable to use Standard Dutch in such a refined and subtle way still remain vulnerable for the kind of linguistic critique Jerom gets to bear (cf. Extract 5). In that way, the Flemish language education policy, built on the promotion of Standard Dutch as a necessary condition for social equality, might actually foster the opposite.

Nevertheless, the question whether these pupils also use (or will use) the standard strategically in non-school situations or in their future lives, has been touched upon only very briefly in this paper. Further research needs to be done to establish whether the pupils capable of using the standard strategically in school contexts are able to do the same in situations outside of the school, by which they would 
contribute to the preservation of the linguistic and social inequality in Flemish society. The current study has demonstrated that we especially need interactional data to answer that question, in addition to observational and interview material.

\section{References}

Archer, M. S. 2012. The Reflexive Imperative in Late Modernity. Cambridge: CUP. doi: $10.1017 / C B O 9781139108058$

Bauman, R. 1987. The role of performance in the ethnography of speaking. Working Papers and Proceedings of the Center for Psychosocial Studies 11: 3-12.

Blommaert, J. 2007. On scope and depth in linguistic ethnography. Journal of Sociolinguistics 11 (5): 682-688. doi:10.1111/j.1467-9841.2007.00346.x

Bourdieu, P. 1991. Language and Symbolic Power. Cambridge MA: Harvard University Press. Bourdieu, P. 2001. Science de la science et réflexivité. Paris: Raisons d'Agir.

Bucholtz, M. 1999. “Why be normal?”: Language and identity practices in a community of nerd girls. Language in Society 28 (2): 203-223. doi:10.1017/So047404599002043

Bucholtz, M. 2011. White Kids. Language, Race, and Styles of Youth Identity. Cambridge: CUP. Coupland, N. 2001. Dialect stylisation in radio talk. Language in Society 30 (3): 345-375.

Coupland, N. \& Kristiansen, T. 2011. SLICE: Critical perspectives on language (de)standardisation. In Standard Languages and Language Standards in a Changing Europe, T. Kristiansen \& N. Coupland (eds), 11-35. Oslo: Novus.

D’Amato, J. 1993. Resistance and compliance in minority classrooms. In Minority Education: Anthropological Perspectives, E. Jacob \& C. Jordan (eds), 181-207. Norwood NJ: Ablex.

D’hoker, M. \& Henkens, B. 2005. Van segmentering naar convergentie. Structuur en karakter van het secundair onderwijs in België in de 20ste eeuw. In Paradoxen van pedagogisering. Handboek pedagogische historiografie, M. Depaepe, F. Simon \& A. Van Gorp (eds), 159-176. Leuven: Acco.

Delarue, S. 2013. Teachers' Dutch in Flanders: The last guardians of the standard? In Language (De)standardisation in Late Modern Europe: Experimental Studies, T. Kristiansen \& S. Grondelaers (eds), 193-226. Oslo: Novus.

Delarue, S. \& De Caluwe, J. 2015. Eliminating social inequality by reinforcing standard language ideology? Language policy for Dutch in Flemish schools. Current Issues in Language Planning 16 (1-2): 8-25. doi:10.1080/14664208.2014.947012

Delarue, S. \& Van Lancker, I. 2016. De kloof overbruggen tussen een strikt onderwijstaalbeleid en een taaldiverse klaspraktijk: Strategieën van Vlaamse leraren en leerlingen. TNTL 132 (2): 85-105.

Deumert, A. \& Vandenbussche, W. 2003. Germanic Standardizations. Past to Present [Impact: Studies in Language and Society 18]. Amsterdam: John Benjamins. doi:10.1075/impact.18

Giddens, A. 1991. Modernity and self-identiy. Self and Society in the Late Modern Age. Cambridge: Polity Press.

Goffman, E. 1981. Forms of Talk. Oxford: Blackwell.

Grondelaers, S. \& van Hout, R. 2011. The standard language situation in the Low Countries: Top-down and bottom-up variations on a diaglossic theme. Journal of Germanic Linguistics 23 (3): 199-243. doi: $10.1017 /$ S1470542711000110 
Heller, M. 2008. Doing ethnography. In Blackwell Guide to Research Methods in Bilingualism and Multilingualism, L. Wei \& M. Moyer (eds), 249-262. Malden MA: Blackwell.

Hymes, D. 1964. Introduction: Toward ethnographies of communication. American Anthropologist 66 (6): 1-34. doi:10.1525/aa.1964.66.suppl_3.02aooo10

Jaspers, J. 2005. Tegenwerken, belachelijk doen. Talige sabotage van Marokkaanse jongens op een Antwerpse middelbare school. Brussel: VUBPress.

Jaspers, J. 2006. Stylizing Standard Dutch by Moroccan boys in Antwerp. Linguistics and Education 17 (2): 131-156. doi:10.1016/j.linged.2006.09.001

Jaspers, J. 2011. Strange bedfellows: Appropriations of a tainted urban dialect. Journal of Sociolinguistics 15 (4): 493-524. doi:10.1111/j.1467-9841.2011.00502.x

Jaspers, J. 2014. Stylisations as teacher practice. Language in Society 43 (4): 371-393. doi: $10.1017 /$ So047404514000360

Jørgensen, J. N. 2008. Polylingual languaging around and among children and adolescents. International Journal of Multilingualism 5 (3): 161-176. doi:10.1080/14790710802387562

Lybaert, C. 2014. Het gesproken Nederlands in Vlaanderen: Percepties en attitudes van een spraakmakende generatie. Gent: Universiteit Gent.

Madsen, L. M. 2014. Heteroglossia, voicing and social categorisation. In Heteroglossia as Practice and Pedagogy, A. Blackledge \& A. Creese (eds), 41-58. Dordrecht: Springer. doi:10.1007/978-94-007-7856-6_3

Martín Rojo, L. 2010. Constructing Inequality in Multilingual Classrooms. Berlin: De Gruyter Mouton. doi: 10.1515/9783110226645

Mehan, H. 1985. The structure of classroom discourse. In Handbook of Discourse Analysis, 3: Discourse and Dialogue, T. A. van Dijk (ed.), 119-131. London: Academic Press.

Milroy, J. 2001. Language ideologies and the consequences of standardization. Journal of Sociolinguistics 5 (4): 530-555. doi:10.1111/1467-9481.00163

Milroy, J. \& Milroy, L. 1985. Authority in Language. London: Routledge \& Kegan Paul. doi: $10.4324 / 9780203267424$

Nicolini, D. 2009. Zooming in and zooming out: A package of method and theory to study work practices. In Organizational Ethnography: Studying the Complexity of Everyday Life, S. Ybema, D. Yanow, H. Wels \& F. H. Kamsteeg (eds), 120-138. Thousand Oaks CA: Sage. doi: 10.4135/9781446278925.n7

Norde, M., De Clerck, B. \& Colleman, T. 2014. The emergence of non-canonical degree modifiers in non-standard varieties of Dutch: A constructionalization perspective. In Extending the Scope of Construction Grammar, R. Boogaart, T. Colleman \& G. Rutten (eds), 207-250. Berlin: De Gruyter Mouton.

Pérez-Milans, M. 2015. Language education policy in late modernity: (Socio)linguistic ethnographies in the European Union. Language Policy 14 (2): 99-107.

doi:10.1007/s10993-014-9354-7

Pérez-Milans, M. 2017. Reflexivity and social change in applied linguistics. AILA Review 29 (1).

Rampton, B. 1995. Crossing. Manchester: St. Jerome.

Rampton, B. 2001. Critique in interaction. Critique of Anthropology 21 (1): 83-107. doi: $10.1177 / 0308275$ X0102100105

Rampton, B. 2003. Hegemony, social class and stylisation. Pragmatics 13 (1): 49-83. doi:10.1075/prag.13.1.03ram

Rampton, B. 2005. Crossing. Language \& Ethnicity among Adolescents. New York NY: Routledge. Rampton, B. 2006. Language in Late Modernity. Interaction in an Urban School. Cambridge: CUP. doi: 10.1017/CBO9780511486722 
Rampton, B. 2010. Linguistic ethnography, interactional sociolinguistics and the study of identities. In Apllied Linguistics Methods: A Reader, T. L. Coffin \& K. O’Halloran (eds), 234-250. London: Routledge/Open University.

Rampton, B., Tusting, K., Maybin, J., Barwell, R., Creese, A. \& Lytra, V. 2004. UK Linguistic ethnography: A discussion paper. <www.ling-ethnog.org.uk>

Silverstein, M. 1993. Metapragmatic discourse and metapragmatic function. In Reflexive Language. Reported Speech and Metapragmatics, J. A. Lucy (ed.), 33-58. Cambridge: CUP. doi:10.1017/CBO9780511621031.004

Smet, P. 2011. Samen taalgrezen verleggen. Conceptnota. <http://www.ond.vlaanderen.be/ nieuws/2011/doc/talennota_2011.pdf>

Van De Mieroop, D., Zenner, E. \& Marzo, S. 2016. Standard and Colloquial Belgian Dutch pronouns of adress: A variationist-interactional study of child-directed speech in dinner table interactions. Folia Linguistica 50 (1): 31-64.

Van Lancker, I. 2016. Standardizing and destandardizing practices at a Flemish secondary school. A sociolinguistic ethnographic perspective on Flemish pupils' speech practices. Taal en Tongval 64: 173-200.

Vandekerckhove, R. 2005. Patterns of variation and convergence in the West-Flemish dialects. In Moderne Dialekte - Neue Dialektologie, E. Eggers, J.E. Schmidt \& D. Stellmacher (eds), 535-552. Stuttgart: Franz Steiner.

Vandenbroucke, F. 2007. De lat hoog voor talen in iedere school. Goed voor de sterken, sterk voor de zwakken. <http://www.coc.be/files/publications/.88/talenbeleidsnota_.pdf>

\section{Appendix. Transcription conventions}

sentence pronounced with interrogative intonation duration of a pause in seconds transcribers' comments part left out from the transcript suggestion of continuation (one used just after and one just before a short pause in between the original sentence and its continuation).

In Extract 1, 2, 3 and 6, the transcription of the recordings has been adapted slightly. Since in the analysis of these extracts the sole focus is on the content of what is said, deletions (e.g. $t$-deletions or $h$-aphaereses) and other phonological deviations from the standard (e.g. der for er 'there') have been adjusted to fit Standard Dutch spelling. However, substandard morpho-syntactic or lexical forms are represented in their original form. This may give the false impression that the language use of the boys is fairly standard. This impression is counterbalanced in Extract 4 and 5, where both content and form are of importance and where, consequently, the transcripts approach the original interaction as closely as possible. 